\title{
THE EFFECT OF THE ECONOMIC CYCLE ON WORKPLACE ACCIDENTS IN SIX EUROPEAN COUNTRIES
}

\author{
Assistant Professor, Anna Maria MOUZA, Technological Educational Institute of \\ Serres, mouza@teiser.gr \\ Dr.Antonis TARGOUTZIDIS, Hellenic Institute for Occupational Health and \\ Safety (ELINYAE), targoutzidis@elinyae.gr
}

\begin{abstract}
The aim of this paper is to investigate the effect of the economic cycle on workplace accidents. In particular, the effect of some major factors of the economic cycle (unemployment, output per capita and unit labor cost) on fatal and non-fatal injuries is examined in six European countries (Finland, Italy, France, Switzerland, Austria and Germany). Correlation analysis and multiple regression analysis are applied, considering relevant data of the selected countries, over the period 1990-2005. The analysis indicates a counter-cyclical behavior of workplace accidents. Output per capita is the only parameter whose impact is statistically significant in all cases. The different effect of the examined factors on workplace accidents and the inter-relations between these factors indicate that an economic model of the workplace is required, if the impact of the economic cycle on workplace accidents is to be studied thoroughly.
\end{abstract}

Keywords: Economic cycle, Workplace accidents, Unemployment, GDP per capita, Unit labor cost.

\section{INTRODUCTION}

Although work is by definition an economic activity, the economic aspect of workplace accidents was not accordingly investigated. Nevertheless, there is a sporadic but long tradition in the study of the relation between the economic cycle and workplace accidents.

The roots of this tradition go back to 1938 when Max Kossoris (1938) found a pro-cyclical relation between (reported) accidents and employment in manufacturing sector in the US. This relation was attributed to a number of reasons: 
- Job tenure: in periods of economic upturns labor demand is increasing and more inexperienced workers are hired; these workers are also the first to lose their jobs in downturns. Therefore the average job tenure decreases in upturns and occupational injuries increase as a result of low experience.

- Work intensity: in economic upturns, work intensity increases to meet demand, which results to an increase of accidents at work.

- Vintage capital: in economic upturns, all resources, including redundant resources (such as old unsafe machinery) are put in full use in order to meet demand. Such unsafe equipment results to an increase of accidents at work.

- Reporting: during downturns workers are less willing to report accidents due to fear of losing their jobs.

Davies and Jones (2005) also added inadequate training (during upturns, the effort to meet demand leaves no room for training, which leads to more accidents) as a potential reason.

A large part of the relevant literature (reviewed in Terrés de Ercilla et al.; 2004) confirms the thesis of Kossoris for a pro-cyclical nature of workplace accidents. However, this statistical relation saw a lot of different and sometimes controversial explanations.

One point of dispute is to detect the factors of the economic cycle which actually affects accident rates. Some researchers investigated the relation between occupational accidents and unemployment rates (TERRES DE ERCILLA et al.; 2004, ESHLER 1977, BOONE and VAN OURS; 2006, SANTANA and LOOMIS; 2004, OSTRY; 1998). Adams (1985) and Partyka (1984) found a high correlation between accidents and employment in the UK. Other researchers (DAVIES and JONES; 2005, BIDDLE; 2004, DAVIES and JONES; 2000, BARTH and WINKER; 2007) focused more on the relation between Gross Domestic Product (GDP) per capita and fatal injuries. Beatson (1995) also argued that the main influence is output per capita rather than employment.

In other research works (RUHM; 2000, TAPIA GRANADOS; 2004) the relation between general health indicators and the economic cycle is examined. In the same direction, the supporters of Risk Homeostasis Theory (WILDE; 1982) argue that people adjust their behavior to external influences (e.g. risks for life, risks for living standards, etc.) by trying to maintain a certain level for total risk. Thus, an increase of income (which reduces the standard of living risks) increases the potential to take risks at work. Similar studies found that in downturns there is a reduction in traffic accidents (WILDE; 1991, WILDE; 1994).

Another part of the relevant literature emphasizes the issue of accident underreporting, arguing that this pro-cyclical behavior of accidents is rather under reporting than actually reduced incidence. More specifically, they argue that data of fatal accidents are more reliable as they are not susceptible to under- 
reporting and these data show no relation to labor market indicators (BOONE and VAN OURS; 2006, SALONIEMI and OKSANEN; 1998).

However, there are also criticisms on whether there is such a pro-cyclical behavior at all. Steele (1974) suggests that the number of occupational accidents should decrease in upturns due to the large costs of absenteeism or replacement of labor during such periods. In the same direction, Nichols (1986) argues that in upturns labor is a scarce resource and workers are in better situation to claim and obtain better working conditions. "During a recession workers accept less favorable working conditions than they normally would" (European Agency for Safety and Health at Work - OSHA; 2001). According to Nichols (2009), the pro-cyclical behavior of accident rates is simply a result of a lag between economic downturns and unemployment.

Terrés de Ercilla et al. (2004) tried to explain these controversies, assuming that both hypotheses (Kossoris' and Nichols') are simultaneously valid and the total effect is the resultant of their combinational impact. This view is general enough to be compatible with any result, but also general enough to require further analysis.

Such an analysis is attempted in this paper and the findings reveal that there are many different factors of the economic cycle that affect the incidence of workplace accidents. In other words, there is probably an underlying model where such factors interact through different weights that may vary between different economies or different time periods. Moreover, there are other factors not related to the economic cycle that also affect their incidence.

Therefore, various factors of the economic cycle (output per capita, unemployment, labor cost) were separately examined as potential determinants and the relation between them was also investigated. For this purpose, multiple regression analysis was applied, considering published data for a number of European countries.

\section{METHODOLOGY}

Six European countries were selected for the reliability of their accident data, which was first assessed after computing the correlation between fatal and nonfatal reported accidents (ROBSON et al.; 2000). The selection of six different countries also helps avoiding potential local confounding elements in the accident reporting system or in the structural characteristics of the economy (e.g. sectoral distribution, labor intensity, etc.). Particularly the countries examined are Finland, Italy, France, Switzerland, Austria and Germany.

Correlation analysis, along with multiple regression analysis were applied to investigate whether there is a relation between occupational accidents (fatal and non-fatal) and unemployment, GDP per capita and unit labor cost, for the period 1990-2005. 
Due to the different nature of statistical data and the long time series required to have reliable results, it was impossible to obtain all data from one source, which necessitated the use of various sources. Specifically, accident data (fatal and non-fatal incidence rates per 100,000 workers) were obtained from the statistical database LABORSTA of the International Labor Organization (ILO). This kind of data cover all workers regardless of their status in employment (i.e. both employees and self-employed, including employers), as well as the whole country and all sectors of the economy.

Unemployment data also came from LABORSTA. Registered unemployment was taken from the Employment office records of each country. Specifically, the "unemployed" comprise all persons above 15 years, who were "without work" (i.e. were not in paid employment or self-employment), "currently available for work", (i.e. were available for paid employment or self-employment) and "seeking work" (i.e. had taken specific steps to seek paid employment or selfemployment) during the reference period.

Annual time series data for GDP per capita (in Euro per inhabitant) were taken from EUROSTAT webpage. Finally, unit labor cost data (average cost of labor per unit of output) for each country were obtained from Organization for Economic Co-operation and Development (OECD).

Apart from the descriptive statistics presented in tables 1-6, multiple regression analysis was applied. Fatal and non-fatal injuries considered as the dependent variables for each country, whereas the set of independent (explanatory) variables includes: GDP per capita, unemployment and unit labor cost. Constant term is included in all equations.

It is recalled that $\bar{y}$ denotes the mean of the corresponding dependent variables, so that the ratio [stand. error (s)]/ $\bar{y}$, is a measure of the coefficient of variation of the dependent variable under consideration. These arithmetic means of fatal and non-fatal injuries show in the first row of tables 1-6. The results obtained are presented in tables 7 and 8.

Table 1: Descriptive statistics and correlation matrix (Finland 1990-2005).

\begin{tabular}{|c|c|c|c|c|c|}
\hline & $\begin{array}{c}\text { Fatal } \\
\text { injuries }\end{array}$ & $\begin{array}{l}\text { Non-fatal } \\
\text { injuries }\end{array}$ & Unemployment & $\begin{array}{c}\text { GDP per } \\
\text { capita }\end{array}$ & $\begin{array}{l}\text { Unit labor } \\
\text { cost }\end{array}$ \\
\hline Mean & 2.7500 & 3455.1250 & 273.3125 & 23368.7500 & 1.2188 \\
\hline Std. Deviation & 0.66433 & 1055.91861 & 87.31760 & 3212.83234 & 3.23836 \\
\hline Fatal injuries & 1 & & & & \\
\hline Non-fatal injuries & $0.762^{\star \star}$ & 1 & & & \\
\hline Unemployment & -0.005 & -.482 & 1 & & \\
\hline GDP per capita & $-0.781^{* *}$ & $-0.529^{*}$ & -0.455 & 1 & \\
\hline Unit labor cost & 0.139 & $0.545^{*}$ & $-0.821^{\star *}$ & 0.213 & 1 \\
\hline \multicolumn{6}{|c|}{$\begin{array}{l}\text { * Significant at } a=0.05 \\
\text { ** Significant at } a=0.01\end{array}$} \\
\hline
\end{tabular}


Table 2: Descriptive statistics and correlation matrix (Italy 1990-2005)

\begin{tabular}{|c|c|c|c|c|c|}
\hline & $\begin{array}{c}\text { Fatal } \\
\text { injuries }\end{array}$ & $\begin{array}{l}\text { Non-fatal } \\
\text { injuries }\end{array}$ & Unemployment & $\begin{array}{l}\text { GDP per } \\
\text { capita }\end{array}$ & $\begin{array}{c}\text { Unit labor } \\
\text { cost }\end{array}$ \\
\hline Mean & 7.4375 & 4259.0625 & 2446.4375 & 19768.7500 & 2.9000 \\
\hline Std. Deviation & 2.15928 & 1091.38050 & 292.62216 & 1296.51777 & 2.92370 \\
\hline Fatal injuries & 1 & & & & \\
\hline $\begin{array}{l}\text { Non-fatal } \\
\text { injuries }\end{array}$ & $0.972^{\star \star}$ & 1 & & & \\
\hline Unemployment & $0.671^{* *}$ & $0.653^{\star *}$ & 1 & & \\
\hline GDP per capita & $-.893^{\star \star}$ & $-.904^{\star \star}$ & $-.669^{\star \star}$ & 1 & \\
\hline Unit labor cost & 0.436 & 0.487 & 0.045 & -0.319 & 1 \\
\hline
\end{tabular}

Table 3: Descriptive statistics and correlation matrix (France 1990-2005)

\begin{tabular}{|l|r|r|r|r|r|}
\hline & $\begin{array}{c}\text { Fatal } \\
\text { injuries }\end{array}$ & $\begin{array}{c}\text { Non-fatal } \\
\text { injuries }\end{array}$ & Unemployment & $\begin{array}{c}\text { GDP per } \\
\text { capita }\end{array}$ & $\begin{array}{c}\text { Unit } \\
\text { labor } \\
\text { cost }\end{array}$ \\
\hline Mean & 5.0500 & 4554.8750 & 2823.3937 & 22362.5000 & 1.3938 \\
\hline Std. Deviation & 1.53536 & 437.39713 & 274.88313 & 1678.44174 & 1.14918 \\
\hline Fatal injuries & 1 & & & & \\
\hline $\begin{array}{l}\text { Non-fatal } \\
\text { injuries }\end{array}$ & $0.970^{* *}$ & 1 & & & \\
\hline Unemployment & 0.165 & .188 & $-0.577^{*}$ & & \\
\hline $\begin{array}{l}\text { GDP per } \\
\text { capita }\end{array}$ & $-.872^{* *}$ & $-.881^{* *}$ & $-0.722^{* *}$ & 0.087 & 1 \\
\hline Unit labor cost & 0.271 & 0.233 & & & \\
\hline $\begin{array}{l}{ }^{*} \text { Significant at } a=0.05 \\
{ }^{* *} \text { Significant at a=0.01 }\end{array}$ & & & & \\
\hline
\end{tabular}

Table 4: Descriptive statistics and correlation matrix (Switzerland 1990-2005)

\begin{tabular}{|l|r|r|r|r|r|}
\hline & $\begin{array}{c}\text { Fatal } \\
\text { injuries }\end{array}$ & $\begin{array}{r}\text { Non-fatal } \\
\text { injuries }\end{array}$ & Unemployment & $\begin{array}{c}\text { GDP per } \\
\text { capita }\end{array}$ & $\begin{array}{c}\text { Unit } \\
\text { labor } \\
\text { cost }\end{array}$ \\
\hline Mean & 2.8937 & $\begin{array}{r}3035.500 \\
0\end{array}$ & 131.2500 & 36481.2500 & 1.8563 \\
\hline Std. Deviation & 1.15728 & $\begin{array}{r}634.7465 \\
6\end{array}$ & 35.35628 & 1391.02780 & 2.98708 \\
\hline Fatal injuries & 1 & 1 & & & \\
\hline $\begin{array}{l}\text { Non-fatal } \\
\text { injuries }\end{array}$ & $0.919^{* *}$ & & & & \\
\hline Unemployment & $-0.593^{*}$ & $-0.655^{* *}$ & & & \\
\hline $\begin{array}{l}\text { GDP per } \\
\text { capita }\end{array}$ & $-0.763^{* *}$ & $-0.714^{* *}$ & 0.223 & & \\
\hline Unit labor cost & $0.532^{*}$ & $0.682^{* *}$ & $-0.856^{* *}$ & -0.109 & \\
\hline $\begin{array}{l}{ }^{*} \text { Significant at a=0.05 } \\
{ }^{* *} \text { Significant at a=0.01 }\end{array}$ & & & & \\
\hline
\end{tabular}


Table 5: Descriptive statistics and correlation matrix (Austria 1990-2005)

\begin{tabular}{|l|r|r|r|r|r|}
\hline & \multicolumn{1}{|c|}{$\begin{array}{c}\text { Fatal } \\
\text { injuries }\end{array}$} & $\begin{array}{c}\text { Non-fatal } \\
\text { injuries }\end{array}$ & Unemployment & $\begin{array}{c}\text { GDP per } \\
\text { capita }\end{array}$ & $\begin{array}{c}\text { Unit } \\
\text { labor } \\
\text { cost }\end{array}$ \\
\hline Mean & 5.7188 & - & 153.8625 & 24056.2500 & 0.7375 \\
\hline Std. Deviation & 1.25231 & - & 24.23086 & 2171.31872 & 1.87754 \\
\hline Fatal injuries & 1 & & & & \\
\hline $\begin{array}{l}\text { Non-fatal } \\
\text { injuries }\end{array}$ & - & 1 & & & \\
\hline Unemployment & $-0.631^{* *}$ & - & & & \\
\hline $\begin{array}{l}\text { GDP per } \\
\text { capita }\end{array}$ & $-0.881^{* *}$ & - & $0.698^{* *}$ & & \\
\hline Unit labor cost & $0.514^{*}$ & - & -0.423 & -0.377 & 1 \\
\hline $\begin{array}{l}\text { * Significant at a=0.05 } \\
\text { ** Significant at } a=0.01\end{array}$
\end{tabular}

Table 6: Descriptive statistics and correlation matrix (Germany 1990-2005)

\begin{tabular}{|c|c|c|c|c|c|}
\hline & $\begin{array}{c}\text { Fatal } \\
\text { injuries }\end{array}$ & $\begin{array}{l}\text { Non-fatal } \\
\text { injuries }\end{array}$ & Unemployment & $\begin{array}{l}\text { GDP per } \\
\text { capita }\end{array}$ & $\begin{array}{c}\text { Unit labor } \\
\text { cost }\end{array}$ \\
\hline Mean & 3.6788 & 4286.1250 & 3737.8750 & 23693.7500 & 1.1500 \\
\hline Std. Deviation & 0.87402 & 901.81675 & 760.33518 & 1620.06944 & 2.02912 \\
\hline Fatal injuries & 1 & & & & \\
\hline $\begin{array}{l}\text { Non-fatal } \\
\text { injuries }\end{array}$ & $0.943^{* *}$ & 1 & & & \\
\hline Unemployment & $-0.763^{\star *}$ & $-0.862^{\star *}$ & 1 & & \\
\hline GDP per capita & $-0.957^{* *}$ & $-0.932^{* *}$ & $0.829^{* *}$ & 1 & \\
\hline Unit labor cost & $0.711^{* *}$ & $0.773^{\star *}$ & $-0.774^{* *}$ & $-0.665^{\star *}$ & 1 \\
\hline
\end{tabular}

Table 7: Regression results for fatal accidents

\begin{tabular}{|l|r|r|r|r|r|r|}
\hline Coefficients & \multicolumn{1}{|c|}{ Finland } & \multicolumn{1}{c|}{ Italy } & \multicolumn{1}{c|}{ France } & Switzerland & Austria & Germany \\
\hline (Explan. variables) & & & & & & \\
\hline Constant & 8.72 & 26.38 & 36.44 & 24.39 & 16.75 & 15.43 \\
\hline GDP per capita & -0.20 & -1.15 & -1.05 & -0.57 & -0.47 & -0.55 \\
\hline (p-value) & 0.00 & 0.00 & 0.00 & 0.00 & 0.00 & 0.00 \\
\hline Unemployment & -0.004 & 0.001 & -0.003 & -0.006 & 0.002 & 0.001 \\
\hline (p-value) & 0.08 & 0.24 & 0.01 & 0.49 & 0.84 & 0.09 \\
\hline Unit labour cost & -0.01 & 0.15 & 0.02 & 0.11 & 0.14 & 0.10 \\
\hline (p-value) & 0.75 & 0.12 & 0.90 & 0.26 & 0.13 & 0.04 \\
\hline Other statistics & & & & & & \\
\hline $\mathrm{R}^{2}$ & 0.77 & 0.84 & 0.93 & 0.79 & 0.82 & 0.94 \\
\hline $\mathrm{R}^{2}$ Adjusted & 0.72 & 0.80 & 0.91 & 0.74 & 0.77 & 0.92 \\
\hline Standard error/ $\bar{y}$ & 0.127 & 0.128 & 0.087 & 0.596 & 0.105 & 0.063 \\
\hline $\mathrm{F}(3,12)$ & 13.84 & 21.35 & 55.27 & 15.42 & 17.67 & 64.60 \\
\hline (p value) & 0.00 & 0.00 & 0.00 & 0.00 & 0.00 & 0.00 \\
\hline
\end{tabular}


Table 8: Regression results for non fatal accidents

\begin{tabular}{|l|r|r|r|r|r|}
\hline \multicolumn{1}{|c|}{ Coefficients } & \multicolumn{1}{c|}{ Finland } & \multicolumn{1}{c|}{ Italy } & \multicolumn{1}{c|}{ France } & \multicolumn{1}{c|}{ Switzerland } & \multicolumn{1}{c|}{ Germany } \\
\hline $\begin{array}{l}\text { Explan. } \\
\text { variables) }\end{array}$ & & & & & \\
\hline Constant & $\begin{array}{r}13763.8 \\
6\end{array}$ & 14354.13 & 13824.46 & 13551.26 & 13681.13 \\
\hline $\begin{array}{l}\text { GDP per } \\
\text { capita }\end{array}$ & -0.31 & -0.60 & -0.30 & -0.29 & -0.37 \\
\hline (p-value) & 0.00 & 0.00 & 0.00 & 0.00 & 0.00 \\
\hline Unemployment & -11.25 & 0.61 & -0.83 & 0.87 & -0.15 \\
\hline (p-value) & 0.00 & 0.26 & 0.00 & 0.81 & 0.49 \\
\hline $\begin{array}{l}\text { Unit labour } \\
\text { cost }\end{array}$ & -2.92 & 94.29 & -17.17 & 138.74 & 99.78 \\
\hline (p-value) & 0.94 & 0.04 & 0.74 & 0.00 & 0.11 \\
\hline Other statistics & & & & & 0.91 \\
\hline $\mathrm{R}^{2}$ & 0.93 & 0.87 & 0.93 & 0.88 & 0.89 \\
\hline $\mathrm{R}^{2}$ Adjusted & 0.92 & 0.84 & 0.91 & 0.85 & 0.069 \\
\hline $\begin{array}{l}\text { Standard } \\
\text { error/ } \bar{y}\end{array}$ & 0.085 & 0.101 & 0.028 & 0.081 & \\
\hline F (3, 12) & 61.27 & 28.055 & 53.30 & 29.56 & 42.90 \\
\hline (p value) & 0.00 & 0.000 & 0.00 & 0.00 & 0.00 \\
\hline
\end{tabular}

In the regression models with fatal injuries as a dependent variable, the independent variable GDP per capita has been expressed in thousand euros (i.e. has been divided by 1000), in order to have a more canonical set of data, from the numerical point of view. Furthermore, it was attempted to run the above regressions considering the logs of the variables, in order to get directly the corresponding elasticities. The inflated value of the condition number however, revealed the existence of multicollinearity, even in a latent form (LAZARIDIS; 2007), so as the analysis was restricted to the initial data. From this point of view, it is worth mentioning that in similar research (TERRES DE ERCILLA et al.; 2004), where the logs of the variables were considered, this condition number was not reported.

\section{RESULTS}

Tables 1 - 6 show a positive correlation between fatal and non-fatal injuries, which is an indication of reliability of accident data in the selected countries. Of course, a degree of under-reporting is possible, but correlation analysis indicates that it is a relatively stable percentage in time and it does not define fluctuations (TERRES DE ERCILLA et al.; 2004).

The relation between unemployment and accident rates (both fatal and nonfatal) is more complex. For three countries (Germany, Austria, Switzerland) there is negative correlation, for Italy there is positive correlation (Figure 1), whereas for two countries (France and Finland) there is no significant 
correlation. However, there is a significant negative correlation between GDP per capita and both fatal and non-fatal injuries in all countries, indicating a counter-cyclical behavior of accidents.

Figure 1: Italy. The trajectory of non-fatal injuries and unemployment, over the period 1990-2005.

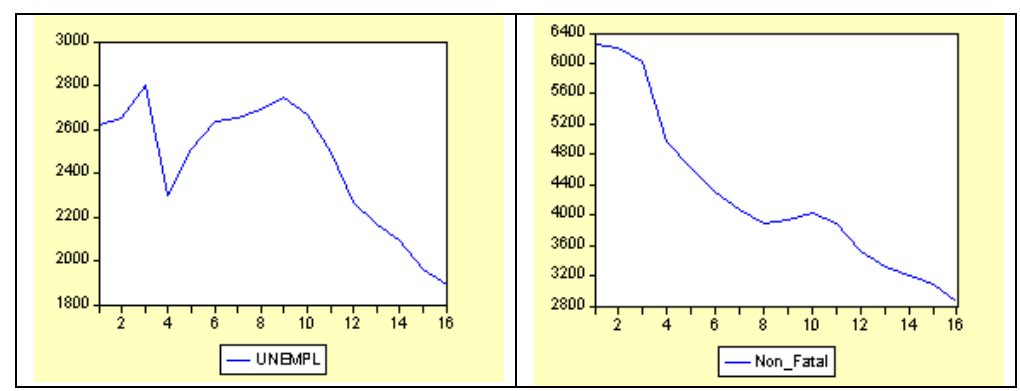

This controversy is explained by the correlation between GDP per capita and unemployment, which is not always negative; it is positive for the cases of Germany and Austria. As Figure 2 shows for Germany, both variables had a time path of the same direction.

Figure 2: Germany. The trajectory of GDP per capita and unemployment, over the period 1990-2005

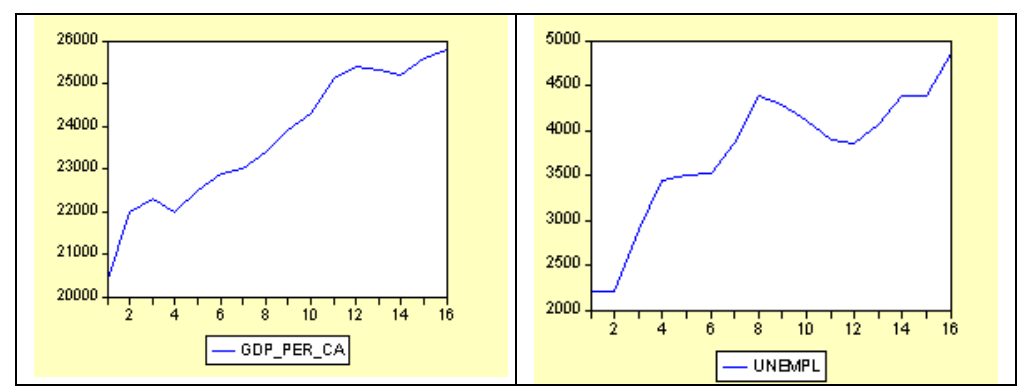

Unit labor cost is positively correlated with fatal accidents (although in some cases this correlation is not significant) and negatively correlated with unemployment. Its correlation with GDP per capita is negative for Switzerland, Italy and Austria and insignificant for Germany (negative), Finland and France (positive).

Tables 7 and 8 verify that the set of independent variables explain $77 \%$ up to $94 \%$ of the total variation of the dependent variables. Observing the values of $F$ statistics and in particular the corresponding $\mathrm{p}$-values (all equal to zero), it can be concluded that the joint effect of the independent variables in explaining the total variation of the dependent variables is significant. 
However, individual tests of significance show that in all cases, GDP per capita is significant, for any significance level. The conclusion is that as GDP increases, fatal and non-fatal injuries decrease, in all six countries. Regarding the rate of decrease, there are large differences from one country to another. An increase of a unit (1000 Euros) of GDP per capita results to a decrease of fatal injuries' rate by 1.15 in Italy, but only 0.2 in Finland. Switzerland and Germany are somewhere in the middle ( 0.57 and 0.55 respectively). For non-fatal injuries, a unit (1 euro) increase of GDP per capita, results to a decrease of the incidence rate from 0.29 (Switzerland) to 0.6 (Italy).

Unemployment has no significant effect in fatal injuries, as Boone and van Ours (2006) also found. However, even for non-fatal injuries this effect is significant in only two cases (Finland and France). In both of them an increase in unemployment results to a reduction of non-fatal injuries. For a unit increase of unemployment this reduction of incidence rate varies from 0.83 (France) to 11.25 (Finland).

It should be recalled that the interpretation of each regression coefficient is subject to the assumption that other independent variables remain unchanged.

Finally, regarding unit labor cost, there are some contradictive results. Like unemployment, it has no significant effect on fatal injuries; for non-fatal injuries its effect is significant in only two cases, i.e. Italy and Switzerland.

\section{DISCUSSION}

These results show a counter-cyclical behavior of workplace accidents. Despite the opposing literature referred to in Paragraph 1 , this outcome was expected, since for the last 15 years there has been an enduring economic upturn (by means of output) and a continuous decrease of workplace accidents in most countries. The analyses of Kossoris were conducted in different historical periods with different economic structures and they do not necessarily apply in the modern economy.

Indeed, it is obvious that the particular structure and characteristics of the economy are those that define the relation between the economic cycle and workplace accidents if any such relation exists at all. Workplace accidents are a labor issue and the economic cycle means different things to the labor market depending on the characteristics of the economy. Therefore, it is more meaningful to analyze the impact of specific parameters of the economic cycle on workplace accidents, rather than the economic cycle as a whole.

The most important finding of this paper is the significant correlation of GDP per capita with workplace accidents, in accordance to previous findings (DAVIES and JONES; 2005, BIDDLE; 2004, DAVIES and JONES; 2000, BARTH et al.; 2007 and BEATSON; 1995). The impact of unemployment was found weaker 
and non-applicable in all cases. The same applies for the impact of unit labor cost.

To better investigate this controversy, the relations between these economic indicators were also investigated. This further examination shows that unemployment and unit labor cost are not always positively correlated to output (GDP) per capita. Actually, three different patterns were identified:

- In Germany and Austria, GDP per capita was positively correlated with unemployment and negatively correlated with unit labor cost. These consequences were negatively correlated with incident rates of occupational accidents in these countries.

- On the other hand, in France and Finland output was negatively correlated to unemployment and positively correlated to unit labor cost. Unemployment was not significantly correlated to incident rates, whereas unit labor cost was positively correlated.

- In Italy and Switzerland, GDP per capita was negatively correlated with unemployment and unit labor cost. The latter was positively correlated with unemployment and incident rate, whereas unemployment was correlated to accident rate positively in Italy and negatively in Switzerland.

The characteristics of each economy are certainly the main causes of these differences. Factors like sectoral distribution of employment (labor intensity), flexibility of labor, etc. can qualitatively differentiate equal figures of employment. For example, self-employment, part-time work or temporary contracting can decrease unemployment without improving the bargaining power of the worker.

It has to be emphasized that GDP per capita is not a measure of workers' income, but a measure of productivity. Income is better indicated by employment and labor unit cost that were not found significantly correlated. This is an indication of a weak impact of the individual motive (and actions) on accident causation. It is also an indication that productivity and safety go together, at least in the long run and in nationwide level (OECD; 1989), as most productive countries are also the safest ones.

Relevant literature has so far indicated some relation between macroeconomic indicators and occupational accidents, although this relation appears to vary between surveys. Moreover, one part of the literature emphasizes more on the behavior and motives of the individual for the causation of accidents (RHT, "procyclical literature") whereas another part implies that the causality of accidents lies with the enterprise ("counter-cyclical literature"). Therefore it is necessary to develop a holistic economic model of the workplace, which will include both the cases of the individual and of the enterprise. 
This model should begin at the micro level, with utility functions of the worker and of the enterprise and has to be expanded in the macro level, where utilities will be defined by macroeconomic indicators like the ones in (BOONE and VAN OURS; 2006). Such an effort requires to also co-examine the interdependences between different macroeconomic factors in the economy.

The causality of workplace accidents is a sophisticated issue with many different aspects; the economic aspect is only one of them. Even if the economic cycles have some impact on workplace accidents, they are definitely not the only factor that defines them. For example, there has been a continuous decrease of workplace accidents in Europe during last decades that was reflecting a number of changes in the work environment, such as better (and safer) technology in machinery, transfer of employment to the less hazardous tertiary sector (OECD; 1989), advances in health care, etc. The impact of any economic development can only be studied in this context. Therefore, a "deflation" of accident rates (own to non-economic factors) has to be imposed if the net effect of economic cycle is to be investigated.

\section{CONCLUSIONS}

This paper attempted is made to study the potential effect of the economic cycle on workplace accidents by separately examining the impact of (and the interdependences between) various factors of the economic cycle. Proper statistical analysis indicates a counter-cyclical behavior of accidents that is significant for only GDP per capita.

However, this indication needs to be further explored in the global context of the workplace. An economic model of the workplace needs to be developed from the micro to the macro level, in order to take all relevant factors into account. The effect of non economic variables should also be taken into consideration.

\section{REFERENCES}

ADAMS J. G. U. (1985): "Risk and Freedom", Transport Publishing Projects, Cardiff.

BARTH A., WINKER R., PONOCNY-SELIGER E. and SÖGNER L. (2007): "Economic growth and the incidence of occupational injuries in Austria", Wiener Klinische Wochenschrift, 119(5-6): 158-163.

BEATSON M. (1995): "Labour Market Flexibility, Employment" Department Research Series, 48. London, The Employment Department

BIDDLE E., Cost of Fatal Occupational Injuries in the United States, 1980-97, Contemporary Economic Policy July (2004) 370-381. 
BOONE J. and VAN OURS J. C. (2006): "Cyclical Fluctuations in Workplace Accidents", Institute for the Study of Labor (IZA), Discussion Paper No. 627. Available at: http://econpapers.repec.org/paper/cprceprdp/3655.htm

DAVIES R. and JONES P. (2000): "An Analysis of Temporal and National Variations in Reported Workplace Injury Rates", Institute for employment and research, The University of Warwick (April 2000). Available at: http://www.hse.gov.uk/statistics/pdf/ier.pdf

DAVIES R. and JONES P. (2005): "Trends and Context to Rates of Workplace Injury”, Research Report 386, Warwick Institute for Employment Research, University of Warwick. Available at: http://www.hse.gov.uk/research/rrpdf/rr386.pdf

ESHLER J. M. (1977): "Filtering of Fatal-Accident Rates, Transportation Research Record", Issue Number 643, Transportation Research Board of the National Academies.

KOSSORIS M. D. (1938): "Industrial injuries and the business cycle", Monthly Labour Review, 66(5): 579-595

LAZARIDIS A. (2007): "A Note Regarding the Condition Number: The Case of Spurious and Latent Multicollinearity", Quality and Quantity, 41(1): 123-135.

NICHOLS T. (1986): "Industrial injuries in British manufacturing in the 1980's - a Commentary on Wright's Article", Sociological Review, 34(2): 290-306

NICHOLS T. (2009): "Labour Intensification, Work Injuries and the Measurement of Percentage Utilization of Labour (PUL)", British Journal of Industrial Relations, 29(4): 569-592.

OECD (1989): "Employment Outlook 1989, Chapter 4. Occupational Accidents in OECD Countries". Available at: www.oecd.org/dataoecd/63/54/3888265.pdf.

OSHA (2001): "FORUM 7, Prevention of Work-related Accidents: a different strategy in a changing world of work? European Conference and Closing Event of the European Week for Safety and Health at Work", Luxemburg: Office for Official Publications of the European Communities. Available at: http://osha.europa.eu/publications/forum/7/forum7_en.pdf/at_download/file

OSTRY A. (1998): "Historical Trends in the Epidemiology of Injury and Industrial Disease at the B.C. Worker's Compensation Board (1950 - 1996)", A Report Prepared for the B.C. Royal Commission on the Worker's Compensation Board. Available at: http://www.qp.gov.bc.ca/rcwc/research/ostry-injury.pdf

PARTYKA S. C. (1984): "Simple Models of Fatality Trends Using Employment and Population Data", Accident Analysis and Prevention, 16: 211 - 222. 
ROBSON L. S., SHANNON H. S., GOLDENHAR L. M. and HALE A. R. (2000): "Guide to Evaluating the Effectiveness of Strategies for Preventing Work Injuries: How to Show Whether a Safety Intervention Really Works". Cincinnati $(\mathrm{OH})$ : Public Health Service, National Institute for Occupational Safety and Health.

RUHM C. J. (2000): "Are recessions good for your health?" Quaterly Journal of Economics, 115(2): 617-650

SALONIEMI A. and OKSANEN H. (1998): "Accidents and fatal accidents - some paradoxes", Safety Science, 29: 59-66

SANTANA V. S. and LOOMIS D. (2004): "Informal Jobs and Non-fatal Occupational Injuries", Annals of Occupational Hygiene, 48(2): 147-157.

STEELE G. (1974): "Industrial Accidents: An Economic Interpretation", Applied Economics, 6(3): 143-155.

TAPIA GRANADOS J. A. (2004): "Mortality and economic fluctuations in Sweden 1800 - 1998", Paper presented at the meeting of the Population Association of America, Boston, April 2004 Available at: http://paa2004. princeton.edu/download. asp? submissionld $=40066$

TERRÉS DE ERCILLA F., MONDELO P. R., CASADO A. E. and VILELLA E. C. (2004): "Economic fluctuations affecting occupational safety. The Spanish case", Occupational Ergonomics, 4: 211-228

WILDE G. J. S. (1982): "The Theory of Risk Homeostasis: Implications for Safety and Health", Risk Analysis, 2: 209-225.

WILDE G. J. S. (1991): "Economics and Accidents: A Commentary", Journal of Applied Behaviour Analysis, 24: 81-84.

WILDE G. J. S. (1994): "Risk Homeostasis Theory and its Promise for Improved Safety" (eds. R. Trimpop and G. J. S. Wilde), Challenges to Accident Prevention: The Issue of Risk Compensation Behaviour. Styx. Groningen, Netherlands. 